KS. WALDEMAR W. ŻUREK SDB* - LUBLIN

\title{
INWENTARZ KOŚCIOLA PARAFIALNEGO W KOSOWIE Z 1770 ROKU
}

Kosów [Poleski], leżący na kresach województwa brzeskiego, już przed 1520 rokiem posiadał drewniany kościół parafialny pw. Świętej Trójcy i Świętego Krzyża, o patronacie szlacheckim. Jego fundatorem był wojewoda trocki Jerzy Sapieha. W czasie reformacji kościół przejęli kalwini. W 1620 roku kolejny właściciel Kosowa Leon Sapieha herbu Lis rozszerzył fundację parafii oraz sprawił do świątyni obraz Matki Boskiej Łaskawej. W kościele tym dnia 12 II 1746 roku został ochrzczony Andrzej Tadeusz Kościuszko, przywódca insurekcji z 1794 roku, który urodził się w niedalekim od Kosowa folwarku Merezowszczyzna. W czasie pożaru miasta w 1872 roku kościół spłonął. Nowy murowany kościół zbudowano w centrum miasta w 1878 roku. Parafia rzymskokatolicka licząca ok. 1500 wiernych należała do dekanatu słonimskiego, w diecezji wileńskiej, w województwie nowogródzkim. Od 1795 roku Kosów należał do Rosji. Po odzyskaniu przez Polskę niepodległości, Kosów Poleski został siedzibą powiatu utworzonego w grudniu 1920 roku. Od lutego 1921 roku wszedł do nowo utworzonego województwa poleskiego. W kwietniu 1935 roku powiat kosowski został zniesiony, a z jego terytorium utworzono powiat iwacewicki. Od 1925 roku parafia kosowska należała do erygowanej w tym roku diecezji pińskiej. Po drugiej wojnie światowej Kosów pozostał w granicach Związku Radzieckiego (Białoruskiej Socjalistycznej Republice Radzieckiej). Od 1991 roku Kosów znajduje się w granicach Białorusi, w obwodzie (województwie) brzeskim, rejon (powiat) Iwacewicze. Świątynia parafialna w mieście była nieprzerwanie czynna w czasie drugiej wojny światowej, jak i w czasach radzieckich, chociaż po 1945 roku przez wiele lat nie było przy niej kapłana. Wierni w kościele gromadzili się w niedziele na modlitwę. Pod koniec lat 80 . XX wieku do świątyni powrócił proboszcz. Parafia należy do dekanatu Prużana, w diecezji pińskiej, w obwodzie brzeskim².

* Ks. Waldemar Witold Żurek SDB - dr hab. historii Kościoła, prof. KUL, dyrektor Ośrodka Archiwów Bibliotek i Muzeów Kościelnych KUL, e-mail: zurek@kul.pl

${ }^{1}$ A. Dudik, W. Rosowski, Pińska diecezja, w: Encyklopedia Katolicka, t. 15, Lublin 1996, kol. 613-615; S. Litak, Kościót łaciński w Rzeczypospolitej około 1772 roku, Lublin 1996, s. 325; G. Rąkowski, Ilustrowany przewodnik po zabytkach kultury na Biatorusi, Warszawa 1997, s. 106. 


\section{Opis fizyczny dokumentu rękopiśmiennego}

Inwentarz kościoła parafialnego $w$ Kossowie $1770 r^{2}$

Dokument rękopiśmienny w formie broszury o wymiarach $220 \times 350 \mathrm{~mm}$ obejmuje jedną legę składającą się z sześciu kart. Składka przeszyta jest jasną lnianą nicią razem z wyklejką i miękką tekturką w odcieniu niebiesko-szarym (tzw. oprawa prosta). Na wierzchniej okładce naklejona jest biała karteczka $(153 \times 78$ mm) z maszynowym napisem: ARCHIWUM PARAFII KOSSÓW, a pod kreską: Inwentarz kościola w Kossowie - 1770 r. (od ks. K. Świątka), po lewej odręczna sygnatura: III/I. Grzbiet w części górnej z obu stron (wierzchniej i spodniej) oklejony jest białą karteczką $(97 \times 39 \mathrm{~mm})$, przy czym na spodniej części powtórzona jest informacja $\mathrm{z}$ karteczki na okładce. W górnej części okładki widoczna jest adnotacja dokonana niebieską kredką: Wizyta generalna $x$. Kadtubowskiego $\underline{1770}$ ) oraz $n r 12$ zapisany czerwoną kredką. Tekst napisano na papierze czerpanym, żeberkowym, o kremowym odcieniu, $\mathrm{z}$ dwoma filigranami (lilia $\mathrm{z}$ literami MB i postacią Matki Bożej z Dzieciątkiem na ręku oraz berło). Karty zostały ponumerowane czerwoną kredką pośrodku górnego brzegu. U dołu pierwszej i ostatniej strony wypisane są pośrodku czerwoną kredką litery $m f$ zakreślone kółkiem (średnica $10 \mathrm{~mm}$ ). Tekst dokumentu zapisany został na stronach 1-8. Pismo naniesione brązowym żelazowo-galusowym atramentem $\mathrm{w}$ języku polskim (poza wstępem i zakończeniem w j. łacińskim), dosyć czytelne, pochylone w prawo. $\mathrm{Na}$ stronach 5 i 6 znajdują się tabele. Tekst kończy się na stronie 8 w 1/3 karty. Karty od 9 do 12 są czyste.

Stan zachowania - 14 sierpnia $2013 \mathrm{r}$.

Dokument zachował się w stanie dobrym, papier czerpany jest doskonałej jakości, karty jedynie na brzegach noszą ślady zabrudzeń i zagięć. Każda karta wzdłuż grzbietu oklejona jest 20-milimetrowym paskiem papieru, z którego wykonana jest wklejka. Świadczy to o wcześniej dokonywanych naprawach. Atrament w znacznym stopniu wyblakł, przybierając kolor jasnobrązowy.

$* * * *$

[k. 1 r] Inventarium Ecclesiae Parochialis Kossovien[sis] sub temp[ore] Visitationis Generalis confectum et Decretum Reformationis a Perillustri Adm[odum] R[evere]ndo D[omi]no D[omi]no Michäele Ioanne Nepomuceno Drzewica Kadłubowski $^{3}$ Ecclesiae Cathedralis Livoniensis scholastico praelato, praeposito

${ }^{2}$ Dokument jest przechowywany w Archiwum Diecezjalnym w Drohiczynie, Zespół Archiwum Parafii Kossów, Sygn. III/I/1 „a”. (Przekazany od ks. Kazimierza Świątka).

${ }^{3}$ Kadłubowski [Jan Nepomucen Józef Borsza-Drzewiecki z Drzewicy] Michał herbu Nałęcz pochodził z rodziny, której nazwisko wywodzi się od wsi Kadłubówka na Podolu. Szlachectwo tej rodzinie nadał im król Zygmunt August w 1564 roku. Michał Kadłubowski był scholastykiem i prałatem katedralnym inflanckim, sufraganem i oficjałem grodzieńskim, białostockim i brzostowskim, proboszczem w Grodnie (1784) i Białymstoku (1791), wizytatorem generalnym diecezji wileńskiej, cenzorem ksiąg. Był kawalerem orderu św. Stanisława. Por. Rodzina. Herbarz szlachty polskiej, opr. S. Urski, t. 6, Warszawa 1909, s. 141; K. Niesiecki, Herbarz Polski, t. 5, Lipsk 1840, s. 7. 
Białostocensi, Brzostovicensi per Podlachiam et tractum Grodnensem Wołkowyscen[si] Officiali ac Generali Visitatore latum a[nno] D[omi]ni $1770 \underline{\text { R. }}$

\section{Visitatio ciborii ${ }^{4}$}

Ciborium snycerskiej roboty biało malowane, częścią wyzłacane, z zamkiem wnętrznym. Pixis pro $S[$ anctis $] s[i] m^{5}$ miedziana, pozłocista, coram $S[$ anctis $] s[i]$ $m o^{6}$ lampa srebrna na łańcuszkach wisząca. Bursa z patyną miedzianą wyzłacaną pro deferendo $S[$ anctis $] \mathrm{s}[i] \mathrm{mo}^{7}$ chorym.

\section{Visitatio baptisterii ${ }^{8}$}

Krzcielnica snycerskiej roboty na postumencie, z wierzchem odmykającym się na zawiasach, wedle krzcielnicy skrzyneczka z zamkiem wnętrznym ad conservanda olea sacra ${ }^{9}, \mathrm{w}$ tejże krzcielnicy jest kociołek mosiężny z łyżką cynową i z wodą do krzczenia.

\section{Visitatio oleo[rum] sacro[rum] ${ }^{10}$}

Olea Sacra w potrójnym naczyniu zamknięte w skrzyneczce przy krzcielnicy.

\section{Visitatio altarium ${ }^{11}$}

Ołtarz wielki snycerskiej roboty, z różnemi akomodacjami, pod polor ${ }^{12}$ biało malowany, po części wyzłacany, w tym ołtarzu jest obraz Beatissimae Virginis de gratis $^{13}$ nazwany. Ofiarowany niegdyś od J[aśnie] W[ielmożnego] Imć Pana Leona Sapiehy ${ }^{14}$ podkanclerzego lit[ewskiego], któremu dostał się od posła papieskiego de Torres ${ }^{15}$, o czym w inwentarzu swoim opisuje J[aśnie] W[wielmożny] Imć

\footnotetext{
${ }^{4}$ Visitatio cibor ii (łac.) - inspekcja puszek eucharystycznych, kielichów.

${ }^{5}$ Pixis pro S[anctis]s[i]mo (łac.) - puszka na Najświętszy (Sakrament).

${ }^{6}$ Coram S[anctis]s[i]mo (łac.) - przed Najświętszym (Sakramentem).

${ }^{7}$ Pro deferendo S[anctis]s[i]mo (łac.) - do zanoszenia Najświętszego (Sakramentu).

${ }^{8}$ Visitatio baptisterii (łac.) - inspekcja chrzcielnicy.

${ }^{9}$ Ad conservanda olea sacra - do przechowywania świętych olejów.

${ }^{10}$ Visitatio oleo[rum] sacro[rum](łac.) - inspekcja świętych olejów.

${ }^{11}$ Visitatio altarium (łac.) - inspekcja ołtarzy.

${ }^{12}$ Pod polor $-\mathrm{z}$ połyskiem.

${ }^{13}$ Beatissimae Virginis de gratis (łac.) - Najświętszej Dziewicy (= Matki Bożej) Łaskawej.
}

${ }^{14}$ Sapieha Leon herbu Lis (1557-1633) - syn Iwana i brat Andrzeja. W młodym wieku oddany na dwór Mikołaja Radziwiłła Czarnego, studiował wraz z jego synami w latach 1570-1573 w Lipsku, gdzie uległ wpływowi protestantyzmu, odszedł od prawosławia i został kalwinem. Dzięki Radziwiłłom dostał się w 1579 roku na dwór Stefana Batorego. W 1580 roku mianowany sekretarzem królewskim, w 1581 roku został awansowany na pisarza litewskiego. W 1585 roku otrzymał urząd podkanclerzego litewskiego, następnie był administratorem skarbu litewskiego, a co za tym idzie zarządcą mennicy w Wilnie. W dużej mierze wpływał na politykę wschodnią Rzeczypospolitej. W 1586 roku przeszedł ostatecznie na katolicyzm. W 1589 roku otrzymał kanclerstwo litewskie, a od 1593 roku pełnił obowiązki trybunała litewskiego. Prowadził kampanię przeciwko powierzaniu urzędów litewskich osobom pochodzącym z Korony. Por. H. Lulewicz, Sapieha Lew herbu Lis, w: Polski Stownik Biograficzny (dalej: PSB), t. 35, Warszawa-Kraków 1994, s. 84-102.

${ }^{15}$ Torres Kosma de (Cosimo, Cosmo, Cosmas) (1584-1642) - włoski duchowny, kardynał. Do godności kardynalskiej został wyniesiony przez papieża Grzegorza XV w 1622 roku. Za pontyfikatu Pawła V sprawował godność protonotariusza. W 1609 roku objął funkcję referendarza Sygnatury - trybunału sądowniczego Stolicy Apostolskiej. W 1621 roku został mianowany arcybiskupem 
ks[iądz] Damascen Lubieniecki ${ }^{16}$ Zakonu Ś[więteg]o Dominika, biskup wołoski. Na tym obrazie [k. 1 v] tabliczek mniejszych i większych 17. Kołnierz srebrny strzały w ręku, promienie i gwiazd 12. Pereł małych sznurek jeden, paciorków sznurków 2, na tym ołtarzu portaty $1{ }^{17}$ konsekrowany od J[aśnie] W[wielmożnego] Imci Ks[iędza] Dowgiały Zawiszy ${ }^{18}$ biskupa wileń[skiego] R[ok]u 1660, na tym ołtarzu lichtarzów cynowych sześć, krucyfiks drewniany.

Po prawej ręce ołtarza wielkiego jest ołtarzyk Ś[więtego] Antoniego snycerskiej roboty, pod polor biało malowany, tamże są lichtarze dwa malowane.

Wchodząc do kościoła po prawej stronie jest ołtarz P[ana] JEZUSA snycerskiej roboty, malowany, mający cierniową koronę srebrną i pasek, sukienkę ma-

adrianopolitańskim. Od 17 III 1621 do 2 XII 1622 roku był nuncjuszem apostolskim w Polsce (z godności tej zrezygnował). W czasie pełnienia misji w Warszawie we wrześniu 1622 roku został mianowany kardynałem z tytułem San Pancrazio (od marca 1623 roku). Podczas konklawe w 1623 roku brał udział w wyborze papieża Urbana VIII. We wrześniu 1624 roku otrzymał arcybiskupstwo Perugia wraz z nowym tytułem Santa Maria in Trastevere. W 1634 roku został przeniesiony na arcybiskupstwo Monreale na Sycylii. W latach 1623-1631 sprawował w kurii urząd kardynała-protektora Królestwa Polskiego. W latach 1634-1635 był skarbnikiem Kolegium Kardynalskiego. W latach 1641-1642 został kardynałem-prezbiterem Kościoła Santa Maria in Trastevere.

${ }^{16}$ Lubieniecki Jan Damascen Mikołaj z Lubieńca herbu Rola (ok. 1651-1714), do dominikanów wstąpił w 1667 roku w Warszawie. Studia filozoficzno-teologiczne odbył w Warszawie i Krakowie i tam przyjął w 1674 roku święcenia kapłańskie. Następnie był wykładowcą teologii tomistycznej w Lyonie, a później w zakonnym studium generalnym w Krakowie i Warszawie (dwukrotnie). Pełnił funkcje przełożonego w Sieradzu, Brześciu Kujawskim i Warszawie, był także teologiem i kaznodzieją na dworze Jana III Sobieskiego. W latach 1700-1703 był profesorem teologii na Angelicum, a od 1704 roku pełnił obowiązki prowincjała. W 1714 roku został konsekrowany w Rzymie na biskupa Bakowa. Jest autorem historii życia papieża Piusa V (w rękopisie). Por. E Zieman, Lubieniecki Jan Damascen, w: Encyklopedia Katolicka (dalej: EK), t. 11, Lublin 2006, kol. 46.

${ }^{17}$ Portatyl (łac. portatile) - ołtarz przenośny.

${ }^{18}$ Jan Karol Zawisza Dowgiałło herbu Płomieńczyk (1597-1661). Kształcił się w Wilnie, Ingolsztacie i Bolonii. Był regentem kancelarii (1641) i referendarzem (1649) Wielkiego Księstwa Litewskiego. W 1689 roku został kanonikiem wileńskim i kaznodzieją katedralnym, następnie proboszczem trockim, wreszcie archidiakonem wileńskim. Był zwolennikiem Jana Kazimierza, w okresie najazdu szwedzkiego towarzyszył królowi na wygnaniu wspomagając go w działaniu. W 1689 roku był delegatem z diecezji wileńskiej na Colloquium charitativum w Toruniu. Dnia $16 \mathrm{X}$ 1656 roku został prekonizowany biskupem wileńskim. Sakrę biskupią przyjął w 1657 roku w Częstochowie. Na skutek zamieszek w kraju nie mógł jednak odbyć ingresu do katedry. Ze względu na najazd wojsk moskiewskich nie mógł rezydować w Wilnie i przebywał w otoczeniu Jana Kazimierza. Zaziębiwszy się w czasie konsekracji kościoła w Olszewie zmarł dnia 9 II 1661 roku. Pochowany został w Rożanie, dawnej siedzibie Sapiehów (obecnie Białoruś), gdzie z obawy przed Szwedami przechowywano wówczas doczesne szczątki św. Kazimierza. Był nieodłącznym towarzyszem króla Jana Kazimierza, stąd dużo podróżował, zaniedbując własne obowiązki. Swoje fundusze zapisał katedrze wileńskiej i na odbudowę kościoła w Oszmianie. Por. Biskupstwo Wileńskie, oprac. J. Kurczewski, Wilno 1912, s. 44-45; s. 114; P. Nitecki, Biskupi Kościoła w Polsce w latach 965-1999. Stownik biograficzny, Warszawa 2000, s. 81-82. 
terialną z kwiatami srebrnemi, zasłonka do tego obrazu niebieska kitajkowa ${ }^{19}$, na mensie portatyl konsekrowany.

Po lewej stronie jest ołtarz Ś[więtej] Anny snycerskiej roboty, z takąż akkomodacją i malowaniem jak ołtarz P[ana] Jezusa, na tym ołtarzu portatyl konsekrowany.

\section{Visitatio cathedrae et confessionalium ${ }^{20}$}

Ambona $\mathrm{z}$ baldachimem drewnianym snycerskiej roboty malowana biało pod polor, niektóre części wyzłacane. Konfesjonały dwa, stolarskiej roboty.

\section{Visitatio chori ${ }^{21}$}

Chór na kościół łamany, malowany, na którym jest organ kupiony przez J[aśnie] W[ielmożnego] [księdza] Kaweckiego przed lat 20. Tamże kotty dwa miedziane stare, item graduał, brewiarze dwa stare i rosarium ${ }^{22}$. Trąb zepsutych para, waltorniów para, wcale ${ }^{23}$ zepsutych, obojów para i basetla w szmatach, item skrzypców starych 2. Legowane kościołowi od Imć P. Burzymowskiego.

\section{Visitatio templi ${ }^{24}$}

Kościół fundowany sub titulo $S[$ anctis $]$ s[i]mae Trinitatis et $S[$ acr $]$ ae Crucis od lat blisko półtorasta przez J[aśnie] W[ielmożnego] Lwa Sapiehy W[ojewod]ę Wileń[skiego], hetmana W[ielkiego] Ks[ięstwa] L[i]t[ewskiego]. Podmurowanie kościoła nadwerężone, wieża malowana czerwono, jak i ściany ad extra ${ }^{25}$ kościelne, z kopułą [k. 2 r] blachą pobitą i krzyżem żelaznym; kościół wewnątrz malowany i stolowany ${ }^{26}$, ławek stolarskiej roboty ośm, orzechową farbą malowane, okna nowe trzy, inne mocno popsute; w kościele przed wielkim ołtarzem grób murowany niewielki. Kościół, że konsekrowany, dowodem są znaki krzyżów na ścianach $\mathrm{z}$ dawna ${ }^{27}$.

\section{Visitatio sacristiae ${ }^{28}$}

Zakrystia przy kościele ma w sobie szafkę starą z trzema szufladami na kielichy. Item szaf dwie na ornaty, lawatyrz ${ }^{29}$ cynowy. Taca miedziana z parą ampułkami niegdyś wyzłacanemi, Item tacek cynowych trzy z dwóma parę ampułkami.

${ }^{19}$ Kitajka - cienka, dosyć gęsta, gładka tkanina jedwabna o splocie płóciennym, jednobarwna lub mieniąca się. Najprostsza i najpospolitsza z tkanin jedwabnych, cieńsza i gorsza gatunkowo od tary.

${ }^{20}$ Visitatio cathedrae et confessionalium (łac.) - inspekcja ambony i konfesjonałów.

${ }^{21}$ Visitatio chori (łac.) - inspekcja chóru.

${ }^{22}$ Rosarium (łac.) - różaniec.

${ }^{23}$ Wcale - całkowicie.

${ }^{24}$ Visitatio templi (łac.) - inspekcja świątyni.

${ }^{25}$ Ad extra (łac.) - od zewnątrz.

${ }^{26}$ Stolowanie - zakładanie ławek kościelnych, stalli. Tu najprawdopodobniej znaczy: posiadający ławki wewnątrz.

${ }^{27}$ Tzw. zacheuszki. Nazwa 12 świeczników przytwierdzonych do ścian kościoła w tych miejscach znajdują sie małe krzyżyki namaszczone podczas jego konsekracji przez bpa. Świece w zacheuszkach zapala się przed sama konsekracją kościoła i w doroczną jej rocznicę (Dedicatio Ecclesiae).

${ }^{28}$ Visitatio sacristiae (łac.) - inspekcja zakrystii.

${ }^{29}$ Lawatyrz, właśc. lawaterz, lawabo, naczynie do obmywania rąk przez kapłana podczas mszy św. (ofiarowania). 
Agenda wielka, małych dwie starych. Baptisatorum, copulator[um] et mortuorum $^{30}$ ksiąg 3. Ewangeliczka jedna.

\begin{tabular}{|c|c|c|}
\hline L.p. & Visitatio supellectilis templia & Sztuki \\
\hline 1. & $\begin{array}{l}\text { Monstrancja partim } \mathrm{b} \text { mosiądzu, partim } \mathrm{z} \text { miedzi, promienie pozłocone } \\
\text { mająca, } \mathrm{z} \text { koroną i melchisedechem niezłożonym }\end{array}$ & 1 \\
\hline 2. & Kielichów podłego srebra wyzłacanych wewnątrz z patynami dwa & 2 \\
\hline 3. & Kielich mosiężny złocony & 1 \\
\hline 4. & Trybularz ${ }^{\mathrm{c}}$ mosiężny stary do noszenia ognia & 1 \\
\hline 5. & Item trybularz nowy $A[n n]$ o 1767 kupiony & 1 \\
\hline 6. & Lichtarzów drewnianych popsutych par & 7 \\
\hline 7. & Krucyfiks duży do processji $A[n n] o$ 1767, malowany & 1 \\
\hline 8. & Krucyfiksów na ołtarzach małych & 4 \\
\hline 9. & Kociołek miedziany do wody święcenia & 1 \\
\hline 10. & Dzwonek na wieży & 1 \\
\hline 11. & Dzwonków w kościele & 4 \\
\hline 12. & Mszałów starych & 3 \\
\hline 13. & Przez ks. [Benedykta] Rumszewicza ${ }^{\mathrm{d}}$ mszał nowy kupiony & 1 \\
\hline 14. & Mszałów żałobnych & 2 \\
\hline 15. & Kapa lamowa ${ }^{\mathrm{e}}$ żółta $\mathrm{z}$ galonem ${ }^{\mathrm{f}}$ szychowym $^{\mathrm{g}}$ & 1 \\
\hline 16. & Kapa gradyturowa stara & 1 \\
\hline 17. & Ornat światły lamowy z manipularzem i stułą & 1 \\
\hline 18. & Ornat czerwony, lamowy, stary & 1 \\
\hline 19. & $\begin{array}{l}\text { Ornat na dnie kaparowym }{ }^{\mathrm{h}}, \mathrm{w} \text { kwiaty złote na bokach szabelowa materia, } \mathrm{z} \\
\text { srebrnemi kwiatami, kitajką podszyty }\end{array}$ & 1 \\
\hline
\end{tabular}

a Visitatio supellectilis templi (łac.) - inspekcja wyposażenia świątyni.

${ }^{\text {b }}$ Partim (łac.) - częściowo.

c Trybularz (łac. turibulum) - naczynie służące do okadzania ołtarza, darów ofiarnych, Najświętszego Sakramentu, Ewangeliarza, krzyża, figur i uczestników liturgii. Wykonywane z metalu, posiada nakrycie (przykrywkę) umocowane na trzech łańcuszkach. Do trybularza z rozżarzonymi kawałkami węgla wsypuje się ziarenka kadzidła.

d Benedykt Rumszewicz - proboszcz w Kosowie od stycznia 1751 roku.

${ }^{\mathrm{e}}$ Lama - gładka, rzadziej wzorzysta tkanina jedwabna z dodatkowym wątkiem kryjącym z wąskich pasków złotej lub srebrnej folii. Używana głównie na kosztowne ubiory świeckie i liturgiczne.

${ }^{\mathrm{f}}$ Galon - wyrób pasamoniczy w formie gładko lub wzorzyście tkanej, rzadziej plecionej taśmy, wykonanej częściowo albo całkowicie z nitek metalowych, metalizowanych, jedwabnych lub bawełnianych. Używany do ozdabiania odzieży, liberii służby, szat liturgicznych, w kapelusznictwie i czapnictwie.

${ }^{g}$ Szych (sych, nędza) - przędza lniana lub bawełniana okręcona spiralnie paseczkiem miedzianym posrebrzanym lub pozłacanym. Warstwa pokrycia była grubsza lub cieńsza, stąd dwa rodzaje szychu: prosty z powłoką cieńszą i grubszy, złocony lub srebrzony grubiej. Stosowany do wyrobu tanika, koronek metalowych i pasamonów oraz do wytwarzania tkanin szychowych.

${ }^{\text {h }}$ Kaparowy - ciemny, zgniłozielony kolor (od barwy marynowanych kaparów).

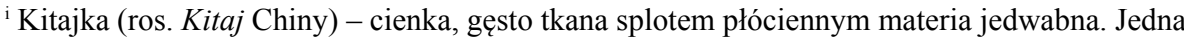
z najstarszych i najprostszych rodzajów tkaniny jedwabnej wyrabianych na Wschodzie.

${ }^{30}$ Baptisatorum, copulatorum et mortuorum (łac.) - (księgi) ochrzczonych, zaślubionych i zmarłych. 


\begin{tabular}{|c|l|c|}
\hline $\begin{array}{c}\text { [k. 2v] } \\
20 .\end{array}$ & Ornat czerwon fioletowy z kwiatami czerwonemi i stułą & 1 \\
\hline 21. & Ornat na fioletowym dnie w kwiaty złote & 1 \\
\hline 22. & Ornatów starych w różnym kolorze, podlejszych & 12 \\
\hline 23. & Krzesło włóczkowe i umbraculum ${ }^{j}$ wyszywane & 1 \\
\hline 24. & Alb nowych z koronkami & 2 \\
\hline 25. & Alb starych & 4 \\
\hline 26. & Komża do kazania & 1 \\
\hline 27. & Komż starych & 2 \\
\hline 28. & Komeszek chłopięcych & 4 \\
\hline 29. & Ręczników & 2 \\
\hline 30. & Pasków włóczkowych & 4 \\
\hline 31. & Tuwaln różnych & 8 \\
\hline 32. & Korporałów starych & 9 \\
\hline 33. & Korporałów nowych & 8 \\
\hline 34. & Puryfikaterzów nowych & 10 \\
\hline 35. & Puryfikaterzów starych & 11 \\
\hline 36. & Humerałów & 5 \\
\hline 37. & Biret & 1 \\
\hline 38. & Chorągwi różnych & 8 \\
\hline 39. & Baldachim adamaszkowy, stary & 1 \\
\hline & $\begin{array}{l}\text { Baldachim na jednym pręcie, karmazynowy, adamaszkowy, fręzlami i galonem } \\
\text { złotym ozdobiony, kitajką karmazynowá podszyty, dany jest kościołowi r[ok] }]\end{array}$ & 1 \\
\hline 40. & $\begin{array}{l}\text { u 1767 od J[aśnie] W[wielmożnej] Imó Pani Bystrej, łowczynej nadwornejk } \\
\text { W[ielkieg]o Ks[ięstwa] L[i]t[ewskiego] }\end{array}$ & 1 \\
\hline 41. & Korporał batysowy & $\begin{array}{l}\text { Item z płótna holen[derskiego] korporałów dwa, dane są od W[ielmożnej] } \\
\text { J[aśnie] P[ani] Justyny Siewieńskiej, cześnikowej woł[kowyskiej] 1767 }\end{array}$ \\
\hline 42. & 1 \\
\hline
\end{tabular}

\section{Visitatio caemiterii ${ }^{31}$}

Cmentarz ogrodzony parkanem dużo zbutwiałym, przed kościołem brama stara, gątami pokryta, z wrotami na biegunach i furtką.

\section{Visitatio campanarii ${ }^{32}$}

Dzwonica wielka po większej części zbutwiała, w niej jest dzwon duży, drugi średni, trzeci mały.

j Umbraculum (łac.) - osłona.

${ }^{k}$ Łowczy nadworny litewski - urząd dworski Wielkiego Księstwa Litewskiego i Rzeczypospolitej. Jego historia sięga czasów Władysława IV Wazy. Na początku miał charakter wyraźnie dworski i obsadzany był przez towarzyszy zabaw królewskich, w XVIII wieku stał się dygnitarstwem. Por. Urzędnicy centralni i dygnitarze Wielkiego Księstwa Litewskiego XIV-XVIII wieku, oprac. H. Lulewicz, A. Rachuba, Kórnik 1994. [strony]

${ }^{31}$ Visitatio caemiterii (łac.) - inspekcja cmentarza

${ }^{32}$ Visitatio campanarii (łac.) - inspekcja dzwonnicy. 


\section{Visitatio xenodochii ${ }^{33}$}

Szpital stary, dranicami ${ }^{34}$ kryty, z sieńmi i izbą od ulicy, na ścienie obraz Ś[więtego] Łazarza i krzyż rżnięty.

\section{Visitatio domus plebanalis ${ }^{35}$}

Budynek nowy co do ścian i dachu zbudowany przez Imć Ks[iędz]a [Benedykta] Rumszewicza, bywszego plebana, udoskonalony zupełnie per modernum parochum $^{36}$.

Po lewej stronie idąc z kościoła budynek stary, gdzie [k. 3 r] chłopcom nauka się daje.

In arca plebanali ${ }^{37}$ syrnik z mlecznikiem niedawno zbudowany, od tego niedaleko jest stajnia, i chlewy przy których stoi zbudowany świron nowy w r[ok]u 1767. Item swironek stary słomą kryty, w tej samej stronie są chlewy dla bydła i wozownia; ex opposito ${ }^{38}$ jest latryna ${ }^{39}$ stara, item przy tej siron słomą kryty. Przy tym jest stodoła stara, item stodoła druga zbutwiała.

Naprzeciw budynku plebańskiego jest budynek folwarczny z oknami, piekarnią, piecami kominami i kuchnią, zbudowany w r[ok]u 1767. Blisko tego budynku jest browar stary, dranicami kryty, za browarem warzywnia, za tą słodownia, po tym łaźnia, zabudowanie stare.

Naprzeciw budynku, w którym się uczą chłopcy, stoi wozownia mała i swironek mały, pod nim jest piwnica stara.

\section{Visitatio subditor[um] plebanalium}

\begin{tabular}{|l|l|l|}
\hline \multicolumn{3}{|c|}{ Iurysdyka albo mieszczanie kościelni } \\
\hline Fran[ciszek] Miranowski & Kazimierz Pawłowski & \\
Marcin Hormanowicz & Antoni Kotlarz & \\
Mikołaj Ataman & Teodora wdowa & Jaśko Kozuszczyk \\
Gabriel Kozuszczyk & Palimon Borodzicz & Piotr Żuk \\
Paweł Borodzicz & Hrehory Romanowski & Marcin Żuk \\
Jan Borodzicz & Iwan Bezruki & Paweł Chwedosik \\
Gabriel Borowski & Kondrat Klimczuk & Wasil Bernacki \\
Michał Rak & Stanisław Krawiec & Fran[ciszek] Malarczuk \\
Jan Rak & Antoni Ostrowski & Jakub Zabłocki \\
Andrzej Soroka & Jan Arabej & \\
Jan Chodakowiec & Leon Przybyły & \\
Jaśko Sopko & Lukasz Bernacki & \\
Piotr Tokarczuk & Michał Żuk & \\
Piotr Bernacki & Jan Przybyły & \\
Pauluczycha wdowa & Fran[ciszek] Kolesnik & \\
\hline
\end{tabular}

${ }^{33}$ Visitatio xenodochii (łac.) - inspekcja szpitala.

${ }^{34}$ Dranica - cienka, wąska deska łupana z pnia dzrewa iglastego, używana w budownictwie drewnainym, zwykle do krycia dachów.

${ }^{35}$ Visitatio domus plebanalis (łac.) - inspekcja domu proboszczowskiego.

${ }^{36}$ Per modernum parochum (łac.) - przez obecnego proboszcza.

${ }^{37}$ In arca plebanali (łac.) - na działce plebańskiej.

${ }^{38}$ Ex opposito (łac.) - naprzeciwko.

${ }^{39}$ Latryna - dół na ekskrementy, prymitywny ustęp. 
Pod temi ludźmi placów jest 27, z których płacić mają po gr 15 na rok, iść do zasiewu do żniwa dni sześć, siódmy gwałtu, do dzwonienia kolejno, do łowienia ryb, z processami via cursoria ${ }^{40}$, na grabarkę do młynu plebańskiego i inna posługa kościelna według dawnych zwyczajów być powinna.

\begin{tabular}{|l|c|c|c|l|c|c|c|}
\hline [k. 3 v] Wieś Storozowszczyzna & syny & woły & konie & & syny & woły & konie \\
\hline Omelian Horbacz & 1 & 1 &, & Wasil Jarocki & & & \\
\hline Ludwik Horbacz &, &, &, & Jakub Smyk & 3 & 2 &, \\
\hline Benedys Horbacz &, & 1 &, & Chwedor Kozuszczyk & 2 & 1 &, \\
\hline Parmen Borowik &, & 2 &, & Hryszko Bielewicz & 2 & 2 &, \\
\hline Janko Haurusik & 1 & 2 &, & Chwedor Pawłowicz & 1 &, &, \\
\hline Demian Arabej & 2 & 2 &, & Jaśko Pawłowicz & 1 & 1 &, \\
\hline Ihnat Sipuzik & 4 & 2 &, & Oleksiej Tokarczuk & 1 & 2 &, \\
\hline Jaśko Andrejczyk & 2 & 1 &, & Tacjana wdowa &, & 1 &, \\
\hline Anton Andrejczyk & 4 & 2 &, & Pauluk Kozuszczyk & 4 &, &, \\
\hline Jaśko Danilczyk &, & 2 &, & Antos Kozuszczyk & 1 & 1 &, \\
\hline Leon Kozuszczyk &, & 1 &, & Maciej Młynarz & 4 & 2 &, \\
\hline Stefan Kozuszczyk &, & 1 &, & & 2 & 1 &, \\
\hline
\end{tabular}

Powinności tej wioski z pół włóki ciągłej, z czym każą chłopi lub żonki, trzy dni służyć mają, gwałtu na rok dni ośm, żyta pół szanka ${ }^{41}$ dziakielne, owsa pół szanka alias miara stara dziakielne, gotowych pieniędzy gr 12 i pół; kura 1, jajec 5 , talkę 1 . Miodem dzielić się z plebanią powinni. Pod tą wioską jest młyn zepsuty i staw zarosły zupełnie.

\begin{tabular}{|c|c|c|c|c|c|c|c|}
\hline \multicolumn{8}{|c|}{ Wieś Chodorki } \\
\hline & syny & woły & konie & & syny & woły & konie \\
\hline Omelian Jakucik &, & 1 & , & Oleksiej Okowity & 3 & 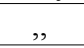 & , \\
\hline Mikołaj Bielewicz & 1 & , & , & Chwedor Arabej & 1 & 1 & 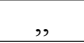 \\
\hline Dominis Siwy & 2 & 2 & , & Jaśko Arabej & 2 & , & 1 \\
\hline Mikołaj Kołot & 2 & 1 & , & Fran[ciszek] Załoha & 2 & 2 & 1 \\
\hline Niczyper Kolesnik & 2 & 2 & 1 & Janko Swikło & 1 & 1 & , \\
\hline Mikołaj Kolesnik & 2 & 2 & , & Stefan Choruzy & 3 & 1 & , \\
\hline Józef Samuszczyk & 1 & 1 & , & Jurkowa Choruzyna & 1 & 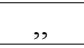 & 1 \\
\hline Mateusz Siwy &, & , & 1 & Maksim Kulhawy & 1 & 2 & , \\
\hline Jaśko Kolesnik & 1 & , & , & Siemion Nowik & 1 & , & , \\
\hline Józef Swikło & 3 & , & , & Ostap Kulhawy & 1 & 2 & 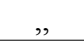 \\
\hline Tomasz Okowity & 1 & 2 & 1 & & & & \\
\hline
\end{tabular}

${ }^{40}$ Via cursoria - drogą pocztową

${ }^{41}$ Szank, szanek - miara objętości towarów sypkich, zwykle zboża, obejmująca 24 lub 48 garnców. 
Powinność tych poddanych z ćwierci osiadłej, z czym każą służyć mają trzy dni, gwałtu na rok dni ośm, żyta pół szanka, owsa pół szanka, gotowych pieniędzy gr 12 i pół, kurę 1 , jajec 5 , talkę jedną, miodem dzielić mają.

\section{Sacra ex obligatione persolvenda ${ }^{42}$}

W poniedziałek za duszę Antoniego, Wojciecha i Felicjanny msza $\underline{1}$, za duszę Lwa i Elżbiety ${ }^{43}$ fundatorów kościoła we środę i piątek msza jedna.

\section{Visitatio personae parochi ${ }^{44}$}

Regit hanc ecclesiam Adm[o]d[u]m] R[evere]nd[us] Adamus Koscia $^{45}$ ab a[nn]o 1765, die 23 Apr[ilis], ordinatus ab Ill[ustrissi]mo ac R[evere]n[dis]s[i] mo Josepho Kierski ${ }^{46} \mathrm{ep}$ [isco]po bolin[ensi], suffraganeo poznanensi [k. 4 r] post liberam resignationem Adm[odum] R[evere]ndi Benedicti Rumsiewicz ad manus Ill[ustrissi]mi loci Ordinarii praesentatus ab Ill[ustrissi]mo Petro Sapieha ${ }^{47}$ palati-

${ }^{42}$ Sacra ex obligatione persolvenda (łac.) - nabożeństwa do odprawienia z obowiązku.

${ }^{43}$ Sapieha Halszka (Elżbieta) z Radziwiłłów (1583-1611). Druga żona Sapiehy Lwa herbu Lis. Mieli córkę Annę (1603-1627), od 1618 roku żonę Albrychta Władysława Radziwiłła oraz trzech synów: Mikołaja (zmarł w wieku dziecięcym), Krzysztofa Mikołaja i Kazimierza Leona. Pochowana pierwotnie w katedrze wileńskiej, następnie przeniesiona została do kościoła św. Michała Archanioła w Wilnie. Por. H. Lulewicz, Sapieha Lew herbu Lis, w: PSB, t. 35, s.103.

${ }^{44}$ Visitatio personae parochi (łac.) - inspekcja osoby proboszcza.

${ }^{45}$ Adam Koscia (II 1731-16 X 1791) - wikariusz i oficjał generalny żmudzki, biskup pomocniczy żmudzki (od 19 VI 1780) i biskup diokleński (od 19 VI 1780), sufragan finlandzki. www. catholic-hierarchy.org.bishop/bkoscia.html (dostęp: 4.02.2016).

${ }^{46}$ Kierski Józef Tadeusz (1706-1783) - urodzony w Kiekrzu (poznańskie), zmarł w Brzozowie. W 1733 roku przyjął święcenia kapłańskie, w 1734 roku objął prepozyturę w kapitule poznańskiej, a w 1736 roku został biskupem pomocniczym diecezji poznańskiej (do 1768 r.). Po śmierci wuja, bpa Stanisława Józefa Hozjusza, pełnił 1738-1739 obowiązki administratora diecezji poznańskiej. Od 1759 roku jako sekretarz wielki koronny (do1763 r.) przebywał na dworze króla Augusta III. W 1768 roku został biskupem przemyskim; w obawie przed konfederacją barską wyjechał za granicę, gdzie przebywał do 1771 roku. Ingres do katedry przemyskiej odbył w 1776 roku. W 1780 roku uzyskał zatwierdzenie Antoniego Wacława Betańskiego na swego koadiutora. W 1772 roku po przyłączeniu części diecezji przemyskiej do Austrii bp Kierski na polecenie władz austriackich przejął zarząd nad częścią diecezji chełmskiej i krakowskiej. W czasie swoich rządów odrestaurował zniszczone kościoły w diecezji, w tym katedrę i dom biskupi w Przemyślu, wybudował także nowy kościół w Brzozowie. W 1760 roku został odznaczony Orderem Orła Białego. Por. T. Śliwa, Kierski Józef Tadeusz, w: Encyklopedia Katolicka (dalej: EK), t. 8, Lublin 2000, kol. 1417-1418.

${ }^{47}$ Sapieha Piotr Paweł herbu Lis (1701-1771) - ożeniony w 1727 roku z bratanicą carycy Katarzyny I (1684-1727), żony Piotra I - Sofią Skowrońską, po śmierci Katarzyny spieniężył dobra w Rosji i przeniósł się z żoną do Polski. Po śmierci ojca, Jana Kazimierza, w 1730 roku stał się jednym z najpotężniejszych magnatów w Polsce. W 1733 roku podpisał elekcję Stanisława Leszczyńskiego i przebywał u jego boku aż do abdykacji króla w 1736 roku. Usiłował stworzyć antyrosyjską koalicję polsko-szwedzką, oferując Szwedom w zamian za interwencję prawa do polskich Inflant, znajdujących się już wówczas w granicach Rosji. Posiadał majątki w Wielkopolsce i na Litwie. W latach 1740-41 spiskował (bez powodzenia) ze Szwedami przeciw Sasom. Z dworem pogodził się w 1744 roku, kiedy otrzymał województwo smoleńskie i Order Orła Białego. Początkowo był przeciwnikiem stronnictwa Czartoryskich (Familia), a po pogodzeniu się z nim poparł podczas elekcji w 1764 roku Stanisława Augusta Poniatowskiego i podpisał jego wybór na tron. Sprzedawszy zadłużone dobra litewskie, osiadł w Wielkopolsce, gdzie od początku organizował działania konfederacji 
no smolen[scensi], collatore legitimo, praeviis cridae literis, demum praevio examine coram examinatore synodali Ill[ustris]s[i]mo R[evere]nd[is]s[i]mo Alexandro Horain ${ }^{48}$ ep[isco]po hiren[si], referendario M[agni] D[ucatus] Lit[uaniae] inst[itu]tus parochus ab Ill[ustris]s[i]mo Excellentissimo D[omi]no Ignatio Jacobo de supremis ducibus roxolanis Massalski ${ }^{49} \mathrm{Ep}$ [isco]po Vilnensi ac ad excipiendas confessiones approbatus. Documenta possessionis legitima approbata vidimus. Incedit vestitu decenti, habet directorium Officii Divini, breviarium synodorum dioecesanarum ac alia ad hanc ecclesiam pertinentia.

\section{Visitatio fundationis eccl[esi]ae Cossow}

Primum fundationis privilegium sub Anno 1520, die 1 Augusti obtulit ecclesiae octo homines cum eo[rum] terris et feris hiis [?] et cum omnibus proventibus. Demum tres tabernas in civitate Kossow, ex duabus harum rector ecclesiae tenetur fovere pro pretio vicarium et ministrum eccl[esi]ae. Ex tertia debet providere ce-

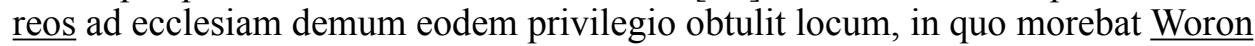

barskiej. Gdy w 1770 roku pruskie wojska weszły na teren jego dóbr, w obawie przed zemstą Prusaków wyjechał do Drezna, a potem do Żyliny, gdzie zmarł. Por. H. Lulewicz, Sapieha Lew herbu Lis, PSB, t. 35, s. 84-102.

${ }^{48}$ Horain Aleksander Kazimierz (1685-1774) - urodzony w Kościeniewiczach koło Wilna. Po studiach w Akademii Wileńskiej i uzyskaniu doktoratu przyjął święcenia kapłańskie i objął probostwo w Niemenczynie. Po przeniesieniu do diecezji żmudzkiej został kanonikiem i prałatem kapituły w Worniach. 24 IX 1731 roku został sufraganem żmudzkim i zarządzał diecezją w imieniu stryja, bpa żmudzkiego Aleksandra Mikołaja (1716-1735). Pełnił także w 1746 roku urząd wizytatora generalnego diecezji wileńskiej i prowizora seminarium duchownego w Wilnie. Podobnie jak cała rodzina Horainów był stronnikiem Familii, dzięki czemu od 1762 roku piastował godność referendarza Wielkiego Księstwa Litewskiego. Został odznaczony Orderem Orła Białego. W 1765 roku złożył rezygnację z urzędu biskupa. Por. J. Bazydło, Horain Aleksander, w: EK, t. 6, Lublin 1993, kol. 1225.

${ }^{49}$ Massalski Ignacy Jakub (1727-1794) - pochodził z ruskiego rodu książęcego. Był synem wielkiego hetmana litewskiego Michała Józefa. Od 1742 roku studiował w Akademii Wileńskiej. Już jako akolita w 1744 roku otrzymał kanonię wileńską, w 1746 roku warszawską, a w 1753 roku żmudzką. W 1745 roku wstąpił do seminarium misjonarzy w Warszawie, następnie studiował na uniwersytecie Sapienza w Rzymie, gdzie uzyskał doktorat obojga praw. Po przyjęciu święceń kapłańskich był proboszczem w Wołpie koło Grodna. Włączył się w działalność polityczną u boku ojca po stronie Familii Czartoryskich. Otrzymał nominację królewską na biskupstwo wileńskie (prekonizowany 29 III 1762 r.). Jako ordynariusz przeprowadził reformę seminarium w Wilnie, powierzając jego prowadzenie misjonarzom. Ogłaszał listy pasterskie, w których oprócz tematów duszpasterskich poruszał kwestie społeczno-ekonomiczne i patriotyczne. Jako biskup propagował i rozwijał szkolnictwo parafialne, zwłaszcza wśród chłopów i ubogiej szlachty. Dbał o podniesienie poziomu naukowego Akademii Wileńskiej. Dążył do stworzenia własnego stronnictwa politycznego, zwracając się przy tym ku Rosji. W 1772 roku brał udział w pracach delegacji sejmowej, przygotowującej traktaty rozbiorowe. Zabronił duchowieństwu wileńskiemu propagowania Konstytucji 3 maja. Przebywając w Warszawie, przyłączył się do konfederacji targowickiej. W 1793 roku został wybrany do Rady Nieustającej. Zredagował uniwersał potępiający powstanie kościuszkowskie. Oskarżony o zdradę, został aresztowany na polecenie T. Kościuszki. Po wybuchu powstania w Warszawie został bez procesu sądowego powieszony przez lud Warszawy w czasie ulicznej egzekucji. W 1795 roku jego szczątki sprowadzono do Wilna. Por. S. Brzozecki, Massalski Ignacy Jakub, w: EK, t. 12, Lublin 2008, kol. 155-156; T. Kasabuła, Ignacy Massalski biskup wileński, Lublin 1998, s. 51-96. 
sutor ad situandam quartam tabernam pro usu parochi. Item terra Kraskowszczyzna et duas alias Pustowszczyzna seu Maciejowszczyzna et alterum Niewiarowszczyzna cum omnibus sylvis, pratis, fluviis, tabelis [?] ad hanc terram pertinenti[bus] in longum et latum, prout ex antiquo erat. Item decimam de omni grano et hortis de curia Kossow et ex altera curiola Szmeytowszczyzna. Item arcam in longum et latum usque ad fluvium alias Do rzeczki. Insuper liberat praefatos homines ac supra scriptas tabernas ab universis, magistratibus, tam a iudicibus et paenis eorum immunitati ecclesiasticae eos adscribendo. Quod privilegium scriptum in pergameno et sigillo appenso munitum Ill[ustrissi]mi Georgii palatini de Trocen-

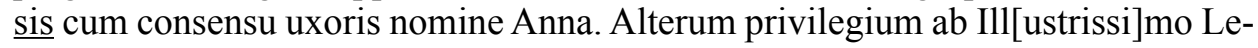
one Sapieha palatino Vilnen[si] supremi exerciti duce Magni Ducatus Lit[uaniae] oblat[um], quo auxit et melioravit primam fundationem fundator adiunxitq[ue] et donavit cum morgis 6, mansis agri 4, Łopieniewszczyzna dictos duosqe pagos primum [k. 4 v], Storozowszczyzna cum mansis agri 12 cum molendino et stagno, alterum pagum Chodorki cum mansis agri 13 cum proventibus tam pecuniariis, quam frumentariis. Ex eo vero, quod fundator additionem meliorationem[que] fecerit fundationis primae, decimas manipulares in veteri fundatione expressas suo cassavit privilegio expresse. Privilegium id oblatum Vilnae a[nn]o D[omini] 1626, die 6 Iunii. Tertium privilegium ab eodem Ill[ustrissi]mo Leone Sapieha palatino Viln[ae], a[nn]o 1627, die 3 Septembris. Conunit iuridicam cum planiciebus. 27 quas incolunt cives ecclesiae dicati.

Słowa kluczowe: Kosów Poleski, historia Kościoła katolickiego, Kresy Wschodnie Rzeczypospolitej

\section{BIBLIOGRAFIA}

\section{Opracowania}

Bazydło J., Horain Aleksander, w: Encyklopedia Katolicka, t. 6, Lublin 1993, kol. 1125.

Brzozecki S., Massalski Ignacy Jakub, w: Encyklopedia Katolicka, t. 12, Lublin 2008, kol. 155-156.

Dudik A., Rosowski W., Pińska diecezja, w: Encyklopedia Katolicka, t. 15, Lublin 1996, kol. 613-617.

Kasabuła T., Ignacy Massalski biskup wileński, Lublin 1998.

Litak S. , Kościół łaciński w Rzeczypospolitej około 1772 roku, Lublin 1996.

Lulewicz H., Sapieha Lew herbu Lis, w: Polski Słownik Biograficzny, t. 35, Warszawa-Kraków, s. 84-104.

Niesiecki K., Herbarz Polski, t. 5, Lipsk 1840, s. 7.

Nitecki P., Biskupi Kościoła w Polsce w latach 965-1999. Słownik biograficzny, Warszawa 2000.

Rąkowski G., Ilustrowany przewodnik po zabytkach kultury na Białorusi, Warszawa 1997. 
Rodzina. Herbarz szlachty polskiej, opr. S. Urski, t. 6, Warszawa 1909, s. 141.

Rosowski W., Pińska diecezja, w: Encyklopedia Katolicka, t. 15, Lublin 1996, kol. 613615 .

Śliwa T., Kierski Józef Tadeusz, w: Encykliopedia Katolicka, t. 8, Lublin 2000, kol. $1417-$ 1418.

Urzędnicy centralni i dygnitarze Wielkiego Księstwa Litewskiego XIV-XVIII wieku spisy opracowali Henryk Lulewicz i Andrzej Rachuba, Kórnik 1994.

Zieman E. , Lubieniecki Jan Damascen, w: Encyklopedia Katolicka, t. 11, Lublin 2006, kol. 46.

Internet

Adam Koscia: www.catholic-hierarchy.org.bishop/bkoscia.html

\title{
THE INVENTORY OF THE PARISH CHURCH IN KOSÓW OF 1770
}

\begin{abstract}
Summary
The presented visitation of the church of Kosów conducted at the end of the 18th century gives us the information about the administration, pastoral ministry and the emoluments of the parish church in Kosów located in the Eastern Borderlands in the Old Polish Period. It also reveals significant figures of political and social life of the time. Its most valuable part contains data referring to the visited parish dedicated to the Holy Trinity and the Holy Cross in Kosów (Poleski) collected by Rev. Jan Nepomucen Kadłubowski; the information ranges from the smallest details or objects to religious buildings (with their equipment and vestments used for worship), residential buildings and outbuildings. The visitation also shows concern for the moral state, material goods of the parish and the order of the liturgy celebrated in the parish church in Kosów.
\end{abstract}

Keywords: Kosów Poleski, the history of the Catholic Church, the Eastern Borderlands 